\title{
Colon Lymphangioma
}

National Cancer Institute

\section{Source}

National Cancer Institute. Colon Lymphangioma. NCI Thesaurus. Code C5500.

A lymphangioma arising from the colon. 